\title{
PENGARUH FOSFOLIPID DALAM PAKAN TERHADAP PEMATANGAN GONAD UDANG WINDU (Penaeus monodon) ASAL TAMBAK $v$
}

\author{
Ketut Suwirya ${ }^{*)}$ dan M. Marzuqi ${ }^{*}$ )
}

\begin{abstract}
ABSTRAK
Fosfolipid berperan dalam transpor lemak dan kholesterol antar organ dan jaringan. Studi penambahan fosfolipid pakan induk udang windu dilakukan dengan tujuan untuk mendapatkan kadar fosfolipid pakan yang optimal dalam pematangan induk udang windu. Penambahan fosfolipid dalam pakan untuk induk udang windu asal tambak telah dicoba dengan kadar 1,50\% (pakan A); 3,10\% (pakan B), 4,40\% (pakan C), dan 6,25\% (pakan D). Pakan percobaan ini diberikan pada udang windu (Penaeus monodon) asal tambak yang bobotnya 92,93 $\pm 14,12 \mathrm{~g}$, selama 72 hari dalam bak $8 \mathrm{~m}^{3}$ dengan kepadatan 14 ekor betina dan 7 ekor jantan. Hasil percobaan menunjukkan bahwa peningkatan fosfolipid pakan berpengaruh terhadap indeks kematangan gonad. Penambahan fosfolipid dalam pakan yang memberikan indek kematangan gonad tertinggi adalah $4,40 \%$ (pakan $\mathrm{C}$ ).
\end{abstract}

ABSTRACT: Effect of dietary phospholipid on gonadal maturation of pond-reared tiger prawn (Penaeus monodon) broodstock. By: Ketut Suwirya and Muhammad Marzuqi

Phospholipid has a role in transportion of lipid and cholesterol to organ and tissues. Study on phospholipid addition on the diet of tiger prawn broodstock had been conducted by the aim to get optimal level of dietary phospholipid in maturation of tiger prawn. Four different dietary levels of phospholipid in diets fed to tiger prawn broodstock were $1.50 \%(\operatorname{diet} A), 3.10 \%(\operatorname{diet} B), 4.40 \%$ (diet $C$ ) and $6.25 \%$ (diet D). Pond-grew tiger prawns weighing $92.93 \pm 14.12 \mathrm{~g}$ were reared for 72 -day in tanks of $8 \mathrm{~m}^{3}$ each with a density of 14 females and 7 males. The result showed that increment of dietary phospholipid significantly affect the gonadosomatic index (GSI). The best level of dietary phospolipid for maturation was $4.40 \%$ (diet $C$ ).

KEYWORDS: Phospholipid, gonadal maturation, Penaeus monodon

\section{PENDAHULUAN}

Di Indonesia masih belum banyak digunakan induk udang asal tambak, namun penelitian ke arah tersebut sudah beberapa kali dilakukan di Loka Penelitian Perikanan Pantai Gondol (Ruchimat et al., 1992; Jufri et al., 1993). Untuk memperoleh mutu calon induk udang asal tambak yang baik, perlu diteliti nutrien yang berpengaruh terhadap kematangan gonad.

Kualitas induk udang windu asal tambak dapat ditingkatkan melalui pengendalian pakan, lingkungan, hormonal dan genetika. Pakan dengan kandungan nutrien yang seimbang diduga dapat mempengaruhi proses pertumbuhan dan perkembangan gonad.
Fosfolipid memegang peranan penting dalam fisiologi krustasea. Fosfolipid berperan dalam transpor lemak dan kolesterol antar organ serta berperan sebagai pemacu pertumbuhan. Kemampuan udang untuk mensintesis fosfolipid sangat rendah sehingga nutrien ini perlu tersedia dalam pakan untuk menunjang pertumbuhannya (D'Abramo et al., 1981).

Udang memerlukan asam lemak esensial (EFA) dan fosfolipid untuk sumber energi bagi pertumbuhannya (Kanazawa et al., 1979; Kanazawa, 1992). Komposisi dan jumlahnya dalam pakan mempunyai peranan penting dalam proses perkembangan gonad udang (Primavera, 1985; Millamena et al., 1984 ${ }^{\mathrm{a}} ; 1984^{\mathrm{b}}$ ). Beberapa penelitian menunjukkan bahwa pematangan gonad dan

\footnotetext{
*) Peneliti pada Loka Penelitian Perikanan Pantai Gondol
} 
pemijahan dipengaruhi oleh kandungan fosfolipid dalam pakan untuk $P$. setiferus (Lawrence et al., 1979; Middleditch et al., 1980) dan P. japonicus (Teshima \& Kanazawa, 1983; Teshima et al., 1989; Alava et al., 1993). Penggunaan lesitin sebagai sumber fosfolipid dalam pakan udang $P$. japonicus adalah sebesar 3,00\% (Alava et al., 1993). Pada berbagai jenis ikan kebutuhan fosfolipidnya belum diketahui (NRC, 1981; 1983; Millikin, 1982), karena ikan dapat mensintesis fosfolipid di dalam tubuhnya seperti hewan darat dan air, namun laju sintesisnya belum bisa mencukupi kebutuhan metabolisme dan fisiologi (Lee \& Sinnhuber, 1972). Ada dugaan bahwa fosfolipid dibutuhkan dalam pakan karena fosfolipid mengandung choline moisty atau fosfatidylkholin (Sillas \& Lutes, 1988). Kholin secara umum diklasifikasikan sebagai vitamin yang esensial dan merupakan komponen penting yang terdapat dalam fosfolipid. Beberapa faktor yang mempengaruhi tingkat kebutuhan fosfolipid pada hewan adalah: 1) aktivitas enzim yang berhubungan dengan sintesis kholin dari beberapa hewan tidak sama, 2) kandungan metionin, betain dan vitamin $\mathrm{B}_{12}$ dalam pakan. Kedua faktor tersebut akan mempengaruhi laju sintesis dari kholin.

Kadar lemak dalam pakan udang berkisar 6 $10 \%$. Di antara komponen lemak yang selalu mendapat perhatian adalah asam lemak tak jenuh (PUFA), fosfolipid dan sterol (Chen, 1993). Di samping itu penambahan fosfolipid dalam pakan akan meningkatkan stabilitas pakan dalam air, sehingga dapat mempertahankan ketersediaan nutrien yang dimakan oleh udang relatif sama dengan komposisi pakan (Chen \& Jenn, 1992).

Dari permasalahan di atas terlihat perlunya percobaan penggunaan fosfolipid dalam pakan induk udang dan untuk mengetahui kebutuhan udang akan fosfolipid. Hal ini diharapkan dapat digunakan untuk meningkatkan kualitas pakan induk udang windu (Penaeus monodon).

\section{BAHAN DAN METODE}

Dalam percobaan ini digunakan induk udang windu asal tambak yang mempunyai ukuran $79,00-115,00 \mathrm{~g}$. Induk udang windu tersebut dipelihara dalam sebuah bak beton bervolume $8 \mathrm{~m}^{3}$. Kepadatan induk adalah 14 ekor betina dan 7 ekor jantan dalam satu bak. Induk udang betina diberi tanda karet bernomor yang berfungsi untuk mengetahui perkembangan bobot tubuh dan gonad dari masing-masing individu selama percobaan.

Induk udang windu yang berasal dari tambak diadaptasikan dengan lingkungan dan pakan buatan selama tujuh hari, kemudian baru dimasukkan ke dalam bak-bak percobaan. Pemeliharaan induk udang ini selama percobaan dengan sistem air mengalir dengan pergantian air per hari sebanyak $150 \%$. Jumlah pakan yang diberikan per hari adalah $3 \%$ bobot udang. Penyiponan sisa pakan dan kotoran dilakukan setiap hari.

Percobaan ini menggunakan rancangan acak lengkap dengan melihat 14 individu induk udang betina sebagai ulangan. Fosfolipid diberikan dalam bentuk lesitin sebanyak $0,00 \% ; 1,50 \%$; $3,00 \%$; dan $4,50 \%$. Dengan perlakuan tersebut, kadar fosfolipid dalam pakan adalah seperti tertera pada Tabel 1.

Percobaan berlangsung selama 72 hari dan ablasi dilakukan pada hari ke-39. Peubah yang diamati adalah bobot tubuh, indeks kematangan gonad (GSI = bobot gonad $\times 100$ /bobot tubuh) dan indeks hepatopankreas (HSI $=$ bobot hepatopankreas x 100/bobot tubuh). GSI dianalisis dengan uji $\mathrm{F}$ dan dilanjutkan dengan uji LSD, sedangkan peubah lain hanya diamati secara deskriptif.

\section{HASIL DAN PEMBAHASAN}

Hasil percobaan ini tertera pada Tabel 2 . Perkembangan gonad induk udang windu dipengaruhi oleh kadar fosfolipid dalam pakan. Hal ini dapat dilihat dari gonad somatik indeks dari setiap perlakuan. Kadar fosfolipid sebesar $4,40 \%$ dalam pakan memberikan kematangan gonad yang paling tinggi dan apabila kandungan fosfolipid pakan diturunkan menjadi $3,10 \%$ atau dinaikkan menjadi $6,25 \%$ dalam pakan maka kematangan gonad cenderung menurun $(P>0,05)$.

Pada Tabel 2 juga terlihat bahwa penambahan fosfolipid dalam pakan sampai kadar tertentu akan menyebabkan bertambah besarnya hepatopankreas somatik indeks (HSI). Hal ini memperlihatkan bahwa fungsi fosfolipid adalah dalam transpor bahan ke hepatopankreas dan selanjutnya diteruskan ke gonad. Pada induk udang yang diberi pakan dengan kadar fosfolipid $1,50 \%$ (pakan A) HSI-nya paling kecil yaitu sebesar 
$2,336 \pm 0,702$, namun dengan peningkatan fosfolipid mulai $3,10 \%$ dalam pakan, sudah dapat meningkatkan HSI menjadi 2,868 $\pm 0,715$. Peningkatan kadar fosfolipid pakan sebesar $4,40 \%$ dan $6,25 \%$ akan menyebabkan HSI sebesar masing-masing 3,069 $\pm 0,713$ dan $2,938 \pm 0,683$, tetapi tidak berbeda nyata dengan perlakuan $3,10 \%$.

Tabel 1. Komposisi pakan yang digunakan dalam penelitian.

Table 1. Composition of the basal diet used in the experiment.

\begin{tabular}{|c|c|c|c|c|}
\hline \multirow{2}{*}{$\begin{array}{l}\text { Bahan pakan } \\
\text { Feed ingredient }\end{array}$} & \multicolumn{4}{|c|}{ Persentase (Percentage) } \\
\hline & $\mathbf{A}$ & $\mathbf{B}$ & $\mathbf{C}$ & D \\
\hline Kasein (Casein) & 55.00 & 55.00 & 55.00 & 55.00 \\
\hline Arginin (Arginine) & 3.00 & 3.00 & 3.00 & 3.00 \\
\hline Sukrosa (Sucrose) & 9.00 & 9.00 & 9.00 & 9.00 \\
\hline$\alpha$-stark $(\alpha-$ Starch $)$ & 3.00 & 3.00 & 3.00 & 3.00 \\
\hline Dekstrin (Dextrine) & 3.00 & 3.00 & 3.00 & 3.00 \\
\hline Kolesterol (Cholesterol) & 1.00 & 1.00 & 1.00 & 1.00 \\
\hline Campuran vitamin (Vitamin mix) ${ }^{*}$ & 0.97 & 0.97 & 0.97 & 0.97 \\
\hline Campuran mineral (Mineral mix) & 8.00 & 8.00 & 8.00 & 8.00 \\
\hline Minyak hati cumi (Squid liver oil) & 7.00 & 7.00 & 7.00 & 7.00 \\
\hline Lesitin (Lecithin) & 0.00 & 1.50 & 3.00 & 4.50 \\
\hline Karagenan (Carrageenan) & 8.00 & 8.00 & 8.00 & 8.00 \\
\hline Selulosa (Cellulose) & 20.03 & 20.03 & 20.03 & 20.03 \\
\hline Jumlah (Total) & 100.00 & 100.00 & 100.00 & 100.00 \\
\hline Protein kasar ( Crude protein) & 42.50 & 42.10 & 41.90 & 43.00 \\
\hline Lemak (Lipid) & 8.25 & 8.30 & 8.21 & 8.60 \\
\hline Fosfolipid (Phospholipid) & 1.50 & 3.10 & 4.40 & 6.25 \\
\hline Non polar lipid & 5.60 & 4.25 & 3.15 & 2.23 \\
\hline
\end{tabular}

*) Vitamin composition (mg/100 g diet) : p-amino benzoic acid 15.80; Biotin 0.63; Inositol 632,00; Niacin 63.20; Ca-panthotenate 94.80; Pyridoxine-HCl 18.96; Riboflavin 12.64; Thiamine-HCl 6.32; Folic acid 1.26; Cyanocobalamine 0.13; Menadion 6.34; Cholecalciferol 1.88; Vitamin C (Phosphitan) 50.00; Vitamin A palmitate 15.00; $\alpha$-tocopherol 50.00).

**) Mineral composition (g/100 g diet) : $\mathrm{K}_{2} \mathrm{HPO}_{4} 1.86 ; \mathrm{Ca}_{3}\left(\mathrm{PO}_{4}\right)_{2} 2.55 ; \mathrm{Mg} \mathrm{SO}_{4} \cdot 7 \mathrm{H}_{2} \mathrm{O} 2.84 ; \mathrm{NaH}_{2} \mathrm{PO}_{4} \cdot 2 \mathrm{H}_{2} \mathrm{O} 0.75$.

Tabel 2. Pertumbuhan, sintasan, indeks perkembangan gonad (GSI), indeks hepatopankreas induk udang windu tambak dengan perbedaan kadar fosfolipid dalam pakan.

Table 2. Growth, survival rate, gonadosomatic index (GSI), hepatosomatic index (HSI) of pond-reared tiger prawn (Penaeus monodon) broodstock fed with different levels of phospholipid.

\begin{tabular}{lcccc}
\hline \multicolumn{1}{c}{ Peubah } & \multicolumn{4}{c}{ Fosfolipid (Phospholipid) (\%) } \\
\cline { 2 - 5 } & $\mathbf{1 . 5 0}(\mathrm{A})$ & $\mathbf{3 . 1 0}(\mathrm{B})$ & $\mathbf{4 . 4 0}(\mathrm{C})$ & $\mathbf{6 . 2 5}(\mathrm{D})$ \\
\hline $\begin{array}{l}\text { Bobot tubuh awal (g) } \\
\text { Initial body weight (g) }\end{array}$ & $92.93 \pm 14.12$ & $93,07 \pm 14.10$ & $92.71 \pm 13.78$ & $93,07 \pm 14.47$ \\
$\begin{array}{l}\text { Bobot tubuh akhir (g) } \\
\text { Final body weight (g) }\end{array}$ & $93.10 \pm 10.10$ & $94.05 \pm 16.21$ & $95.60 \pm 14.51$ & $94.00 \pm 15.45$ \\
$\begin{array}{l}\text { Indeks perkembangan gonad (\%) } \\
\text { Gonado Somatic Index/GSI (\%) }\end{array}$ & $0.765 \pm 0.399^{\mathrm{a}}$ & $1.165 \pm 0.862^{\mathrm{ab}}$ & $1.939 \pm 1.578^{\mathrm{b}}$ & $1.200 \pm 0.946^{\mathrm{ab}}$ \\
$\begin{array}{l}\text { Indeks hepatopankreas (\%) } \\
\text { Hepatosomatic index/HSI (\%) }\end{array}$ & $2.336 \pm 0.702^{\mathrm{a}}$ & $2.868 \pm 0.715^{\mathrm{ab}}$ & $3.069 \pm 0.713^{\mathrm{b}}$ & $2.938 \pm 0.683^{\mathrm{ab}}$ \\
\hline
\end{tabular}


Pada Tabel 2 terlihat bahwa kadar fosfolipid $4,40 \%$ dalam pakan akan menyebabkan fungsi hati maksimum (HSI paling tinggi) dan kematangan gonad paling cepat (GSI paling tinggi). Kadar fosfolipid pakan optimum akan menyebabkan GSI dan HSI menjadi maksimum, penurunan atau penambahan kadar fosfolipid pakan dari kadar optimum akan menyebabkan menurunnya GSI dan HSI.

Fosfolipid dibutuhkan oleh udang untuk memudahkan transpor lemak dan kholesterol ke berbagai organ dan jaringan tubuh (Teshima et $a l .$, 1986). Di samping itu, pematangan gonad udang penaeid memerlukan fosfolipid dalam pakan namun kadarnya berbeda bergantung pada spesies. Beberapa penelitian menunjukkan bahwa pematangan gonad dipengaruhi oleh lesitin (fosfolipid) dalam pakan untuk udang $P$. setiferus sebesar 3,00\% (Lawrence et al., 1979; Middeditch et al., 1980); P. japonicus sebesar 3,00\% (Teshima dan Kanazawa, 1983; Teshima et al. 1989; Alava et al., 1993) dan P. indicus sebesar 1,50\% (Suwirya et al. 1996)

\section{KESIMPULAN}

Kandungan fosfolipid sebesar $4,40 \%$ dalam pakan induk udang windu asal tambak adalah optimal untuk menunjang pematangan gonad, dilihat baik dari indeks somatik gonad maupun hepatopankreas.

\section{DAFTAR PUSTAKA}

Alava, R.A., A. Kanazawa, S. Teshima dan S. Koshio. 1993. Effect of phospholipids and n-3 highly unsaturated fatty acids on ovarian development of kuruma prawn. Bu!l. Jap. Soc. Sci. Fish. 59: 345351.

Chen, H.Y. 1993. Recent advances in nutrition of Penaeus monodon. Journal of the World Aquaculture Society 24(2): 231-240.

Chen, H.Y. and J.S. Jenn. 1992. Increased pellet water stability by the supplementation of phospolipid and its effect on shrimp growth. Asian Fish. Sci. 5: 211217.

D' Abramo, L.R., C.E. Bordner, D.E. Conklin and N.A. Baum. 1981. Essentiality of dietary phosphatidylcholine for the survival of juvenile Lobsters. J. Nutr. 111: 425-431.
Jufri, M. Marzuqi, N.A. Giri dan C. Kuma. 1993. Pengaruh penambahan vitamin E terhadap perkembangan gonad udang windu (Penaeus monodon) asal tambak. J. Penel. Budidaya Pantai. 9 (2): 117 126

Kanazawa, A.., S. Teshima and M. Ondo. 1979. Requirements of prawn, Penaeus japonicus, for essential fatty acids. Mem. Fac. Fish., Kagoshima Univ. 28:27-33.

Kanazawa, A. 1992. Recent advances in penaeid nutrition in Japan. In. G.L. Allan and W. Dall (Eds.). Proc. Aquaculture Nutrition Workshop, Salamander Bay, Australia. pp. 64-71.

Lawrence, A.L., D. Ward, S. Missler, A. Brown, J. McVey and B.S. Middleditch. 1979. Organ indices and biochemical levels of ova from penaeid shrimp maintained in captivity versus those captured in the wild. Proceedings of the World Mariculture Society, 10: 453-463.

Lee, D.J. and R.O. Sinnhuber. 1972. Lipid requirement. In. J.E. Halver (Eds.). Fish nutrition Academy Press. Inc. New York. p. 145-180.

Middleditch, B.S., S.R. Missler, H.B. Hines, J.P. McVey, A. Brown, D.G. Ward and A.L. Lawrence, 1980. Metabolic profiles of penaeid shrimp : Dietary lipids and ovarian maturation. J. Chromathography. 195: 359-368.

Millamena, O.M., R.A. Pudadera and M.R. Catacutan. $1984^{\mathrm{a}}$. Variation in tissue lipid and fatty acid composition during ovarion maturation of unablated and ablated Penaeus monodon broodstock. Proceeding of the First International Conference on the Culture of Penaeid Prawns/Shrimps. SEAFDEC, Aquaculture Departement, Iloilo. Philippines.

Millamena, O.M., R.A. Pudadera and M.R. Catacutan. $1984^{\prime \prime}$. Effect of diet on reproductive performance of ablated Penaeus monodon broodstock. Proceeding of the First Internatinal Conference on the Culture of Penaeid Prawns/Shrimps. SEAFDEC, Aquaculture Department, Iloilo, Phillipines.

Millikin, M.R. 1982. Qualitative and quantitative nutrient of fishes: a Review. Fish Bull. 80: 655 686.

NRC. 1981. Nutrient requirement of domestic animal nutrient requirement of cold water fishes. National Academy Press. Washington, DC., USA. p. 63.

NRC. 1983. Nutrient requirement of domestic animal nutrient requirement of warmwater fishes and shellfishes. National Academy Press. Washington, DC., USA. p. 102. 
Primavera J.H. 1985. A review of maturation in close thelicum penaeid prawn. Proceeding of the First International Conference on the Culture of Prawns/ shrimps. SEAFDEC, Aquaculture Department, Iloilo, Philippines. p. 47-64

Ruchimat, T., Tridjoko, T. Sutarmat dan S. Lante. 1992. Pematangan ovari udang windu dengan penyuntikan ekstrak torasik ganglion lobster. J. Penel. Budidaya Pantai. 8 (3): 9-14.

Sillas, O.H. and P.B. Lutes. 1988. A Preliminary study on the non-essentiality of lecithin for hatchery produced juvenile white Sturgeon. Aquaculture. 68: 353-360,

Suwirya, K., M. Marzuqi, Haryanti. 1996. Pengaruh lesitin dalam pakan terhadap pematangan gonad dan pemijahan udang putih (Penaeus indicus) asal tambak intensif. Jurnal Penelitian Perikanan Indonesia 2(3): 46-49.

Teshima, S. and A. Kanazawa. 1983. Variation in lipid composition during the ovarian maturation of the prawn. Bull. Jap. Soc. Fish. 49(6): 957-962.

Teshima, S., A. Kanazawa and Y. Kakuta. 1986. Role of dietary phospholipids in the transport of $\left({ }^{14} \mathrm{C}\right)$ cholesterol in the prawn. Bull. Jap. Soc. Fish. 52:519-524.

Teshima, S., A. Kanazawa, S. Koshio and K. Horinouchi. 1989. Lipid metabolism of the prawn Penaeus japonicus during maturation: variation in lipid profiles of the ovary and hepatopancreas. Comp. Biochem. Physiol. 92b (1): 45-49. 